\title{
Pools and fluxes of carbon in three Norway spruce ecosystems along a climatic gradient in Sweden
}

\author{
Dan Berggren Kleja • Magnus Svensson • Hooshang Majdi • \\ Per-Erik Jansson • Ola Langvall · Bo Bergkvist • Maj-Britt Johansson • \\ Per Weslien · Laimi Truus · Anders Lindroth · Göran I. Ågren
}

Published online: 23 January 2008

(C) Springer Science+Business Media B.V. 2008

\section{Erratum to: Biogeochemistry (2007) \\ DOI 10.1007/s10533-007-9136-9}

The $9^{\text {th }}$ authors name should appear as Laimi Truus and not Laimi Truusb and it is Tallinn University, Tallinn and not Tallin University, Tallin.

The online version of the original article can be found under doi:10.1007/s10533-007-9136-9.

\section{B. Kleja $(\bowtie)$}

Department of Soil Sciences, Swedish University of Agricultural Sciences, 7014, SE 75007 Uppsala, Sweden e-mail: Dan.Berggren@mv.slu.se

M. Svensson · P.-E. Jansson

Department of Land and Water Resources Engineering, Royal Institute of Technology, Stockholm, Sweden

H. Majdi · G. I. Ågren

Department of Ecology, Swedish University of Agricultural Sciences, Uppsala, Sweden

O. Langvall

Asa Experimental Forest and Research Station, Swedish University of Agricultural Sciences, Lammhult, Sweden
B. Bergkvist

Department of Ecology, University of Lund, Ecology

Building, Lund, Sweden

\section{M.-B. Johansson}

Department of Forest Soils, Swedish University of Agricultural Sciences, Uppsala, Sweden

P. Weslien

Department of Plant and Environmental Sciences, Göteborg University, Goteborg, Sweden

L. Truus

Institute of Ecology, Tallinn University, Tallinn, Estonia
A. Lindroth
Department of Physical Geography and Ecosystem
Analysis, Lund University, Lund, Sweden 